\title{
SEP とサーモグラフィーによる視床出血の神経症候の評価
}

\section{趙 桂萍 長坂 光泰 清水 庸夫}

要旨：視床出血患者32症例の神経症状, $\mathrm{CT}$ 上の血腫の部位抢よび大きさ, SEP, サーモグラ フィーとの関連を検討した。神経症状はしびれ (21例), 冷感 ( 8 例), 熱感 ( 3 例), 疼痛 (4 例）等の自覚的感覚障害と表在感覚低下 (19例), 深部感覚低下 (14例), 半身麻痺 (25例) な どであった。CT上，視床出血を外側核型（21症例），内側核型（4 症例)，混合型（7症例）の 3 型に分類した. SEP の異常は63\%で，自覚的感覚障害との関連ではしびれ (76\%), 冷感 $(75 \%)$, 熱感 $(67 \%)$, 疼痛 $(50 \%)$ の順に異常を呈した。また, 重度表在感覚低下の $82 \%$, 重 度深部感覚低下の $86 \%$, 外側核型の $67 \%$ SEP の異常があり，とくに波形の消失が高率であつ た.サーモグラムは $66 \%$ に患側の高温または低温の体表温異常を認め，しびれ感の $67 \%$ ，運動 麻痺の $72 \%$, 冷感の $75 \%$, 熱感の $67 \%$ に異常を認めた。冷感や熱感を有する症例ではサーモグ ラム上でも同じ傾向を示した。また SEP と同様に，重度表在感覚低下例の $82 \%$, 重度深部感 覚低下例全例でサーモグラムに異常がみられたＳSEPの異常とサーモグラムの異常の併存は $41 \%$ で, 外側核型に多くみられた. 視床出血の CT 分類は残存する神経症候に有用であり, SEP は重度他覚的感覚障害の評価に役立ち, サーモグラフィーは重度自覚的と他覚的感覚障害の評 価に有用と考えられた。

Key words : thalamic hemorrhage, CTscan, SEP, thermography

(脳卒中19 : 19-25, 1997)

\section{はじめに}

視床障害は, 古典的な Dejerine-Roussy 症候群(1906 年)"で代表され, 今日ではさらに同名半盲, 聴力障害, 強迫笑, 自律神経障害などさまざまな症状2)が加えら れている. 特に視床は感覚伝導路の中継核として重要 であり ${ }^{3)}$ しかも $\mathrm{Vc}$ ニューロンははっきりした機能的 な局在までが判明している4.

一方, 視床出血は高血圧性脳出血の $14 \%$ ３5\% ${ }^{5) ~ 7) ~}$ を占め, しばしば遭遇する疾患である。臨床上, 視床 出血による感覚障害で問題になるのはしびれ感と疼痛 である. 特にしびれ感は, かなりの頻度でみられ5)，し かも最も患者を悩ませている，またしびれ感を訴える 患者の中には, 同時に肢体の冷感又は熱感を訴える患 者も少なくない.このため, 視床出血患者に扔いて, その臨床症状を客観的に把握することは重要である。 近年 SEP (somatosensory evoked potentials) は

関東脳神経外科病院

(1996年 9 月30日受付，1996年12月25日受理)
中枢性疾患の感覚障害によく応用され, 脳血管障害と の関係についても多く研究されている ${ }^{8) \sim 13)}$.

しかし，感覚障害との関係をサーモグラフィーとの 併用で,多角的に検討した報告はみられない.今回我々 は, 視床出血患者の感覚障害, 運動麻痺と患側上肢で のSEP とサーモグラフィーの関係を検討した。

\section{対象および方法}

頭部 CT 上，血腫の大部分が視床に限局するものを 対象とした。また，血腫が大きく意識障害が続いてい る症例や症状が消失した症例は除外した。症例は 32 例 (男性20例，女性12例) で，年齢は46〜 76歳 (平均年齢 62.6歳), 血腫側は右13例, 左19例であった。発症から 検査施行までの期間は 3 力月未満 (平均28日間) 14例, 3 力月から 5 年 6 力月間 (平均 3.2 年間) 18 例であった.

CT 上の血腫存在部位により次の様に分類した（図 1 ). 視床内の内側髄板の内側に存在する中心核や背内 側核などを中心とする内側核型, 内側髄核の外側に存 在する外側腹側核や後外側腹側板などを中心とする外 側核型，およびやや大きく両者に及んでいる混合型と 


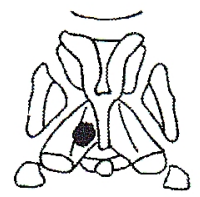

内側核型 ( 4 例)

(中心が內側檤板の內側に存在)

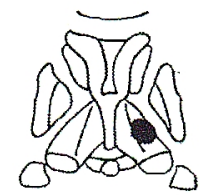

外側核型 ( 21 例)

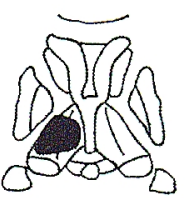

混合型 ( 7 例)

（中心が内側䯣板の外側に存在）（出血が視床全体に及んでいる）

図 1 視床出血の分類（典型例）

Lた.

SEP は NEC Synax 1100 を使用し, 刺激電極は患側 と健側の両者手関節部正中神経上に置き，電極の間隔 は $2.5 \mathrm{~cm}$ で，刺激間隔 $2 \mathrm{~Hz}$ ，持続時間 $0.2 \mathrm{~ms}$ の短形波 を用い経皮的に刺激した。刺激強度は母指球筋の収縮 が十分得られる程度とした。関電極は刺激と反対側の 頭頂と外耳孔を結ぶ線上で, 頭頂から $7 \mathrm{~cm}$ 外側, $2 \mathrm{~cm}$ 後方の点（Shagass の点）とし，基準電極を関電極と 同側の耳染とし, 分析時間 $50 \mathrm{~ms}$, 加算回数 $72 \sim 200$ で上 肢の皮質 SEP 測定した。SEPの評価屾， $\mathrm{N}_{20}$ 頂点潜 時延長と波形消失で行い, 健側に比べ $0.8 \mathrm{~ms}$ 以上の潜 時延長を有意とした（図 2).

サーモグラフィーは日本電子サーモピュアを使用 し, 室温に打ける左右上肢皮虞温を測定し, 左右差の $0.5^{\circ} \mathrm{C}$ 以上を異常と評価した（図 3 )。また 8 例（サー モグラム上での正常 3 例，患側低温 1 例，患側高温 4 例）は $15^{\circ} \mathrm{C}$ 寒冷負荷，寸な放方， $15^{\circ} \mathrm{C}$ の水に両手を 3 分間入水後, 1 分， 3 分，5分，10分の皮膚温測定 した。その評価は，左右の皮膚温の回復の差をもって 暴常とした。

\section{結果}

\section{1. 臨床症状（表 1 )}

自覚的感覚障害は，患側肢のしびれ感 21 例，冷感 8 例，熱感 3 例，自発痛 4 例が訴えられた。他覚的感覚 障害註，表在感覚低下19例（軽度（6９/10）8例，重 度 (5/10以下) 11例), 深部感覚低下 14 例（軽度 7 例, 重度 7 例)であった。運動麻痺は25例で, 精神症状が 3 例，下随意運動が 5 例でみられた。

\section{CT 上の血腫の大きさと部位（表 2)}

血腫の大きさは2 $35 \mathrm{~m} l$ で, $10 \mathrm{~m} l$ 以下の小血腫 18 例 (平均 $5.95 \mathrm{~m} l$ ), $10 \mathrm{~m} l$ 以上の大血腫 14 例 (平均 14.96 $\mathrm{m} l)$ であった。血腫の存在部位は, 内側核型 4 例 (13\%)，外側核型21例 (66\%)，混合型 7 例 (22\%) で あった。
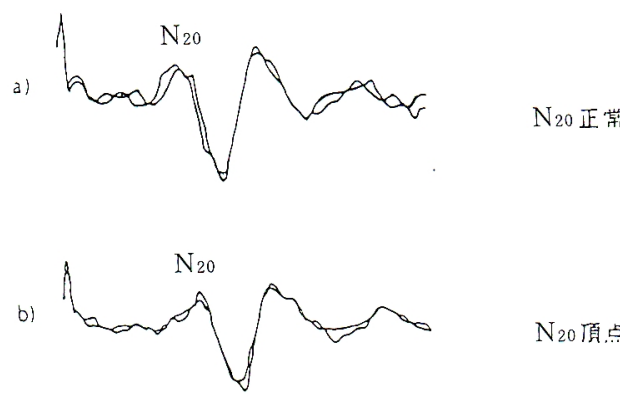

$N_{20}$ 面点潜時延長

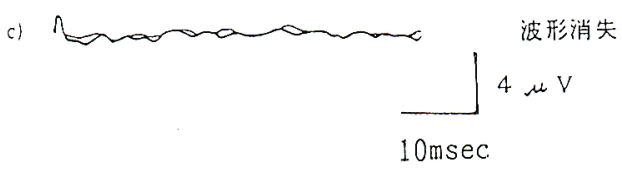

図 2 正中神経刺激 SEP

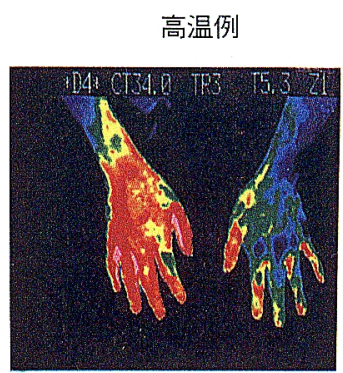

患側
健側
低温例

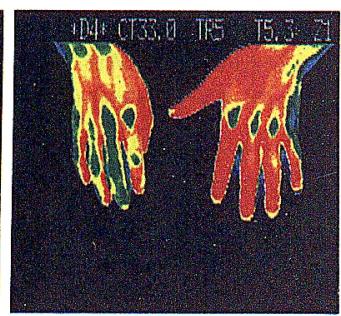

患側
高温例は約 $2.5^{\circ} \mathrm{C}$ の温度差 低温例は約 $2^{\circ} \mathrm{C} の$ 温度差

図3手のサーモグラム

赤が浱い程, より高温. 青が浱い程, より低温を示し ている.

\section{SEP}

SEP は20例（63\%）に異常がみられ，11例で波形消 
表 1 臨床症候と SEP.サーモグラム

\begin{tabular}{|c|c|c|c|c|c|c|}
\hline \multirow{2}{*}{ 臨床症候 } & \multicolumn{3}{|c|}{ SEP } & \multicolumn{3}{|c|}{ サーモグラム } \\
\hline & 消失 (11例) & 延長 ( 9 例) & 正常 (12例) & 低温 (12例) & 高温 ( 9 例) & 正常 (11例) \\
\hline \multicolumn{7}{|l|}{ しびれ感 } \\
\hline 有り (21例) & 10 & 6 & 5 & 8 & 6 & 7 \\
\hline 無し (11例) & 1 & 3 & 7 & 4 & 3 & 4 \\
\hline \multicolumn{7}{|l|}{ 冷 感 } \\
\hline 有り( 8 例) & 2 & 4 & 2 & 4 & 2 & 2 \\
\hline 無し (24例) & 9 & 5 & 10 & 8 & 7 & 9 \\
\hline \multicolumn{7}{|l|}{ 熱 感 } \\
\hline 有り( 3 例) & 2 & 0 & 1 & 0 & 2 & 1 \\
\hline 無し (29例) & 9 & 9 & 11 & 12 & 7 & 10 \\
\hline \multicolumn{7}{|l|}{ 自発痛 } \\
\hline 有り（ 4 例） & 1 & 1 & 2 & 3 & 1 & 0 \\
\hline 無し (28例) & 10 & 8 & 10 & 9 & 8 & 11 \\
\hline \multicolumn{7}{|l|}{ 表在感覚低下 } \\
\hline 有り (19例) & 10 & 2 & 7 & 4 & 9 & 6 \\
\hline 軽度 ( 8例) & 2 & 1 & 5 & 1 & 3 & 4 \\
\hline 重度 (11例) & 8 & 1 & 2 & 3 & 6 & 2 \\
\hline 無し (13例) & 1 & 7 & 5 & 8 & 0 & 5 \\
\hline \multicolumn{7}{|l|}{ 深部感覚低下 } \\
\hline 有り(14例) & 8 & 2 & 4 & 5 & 6 & 3 \\
\hline 軽度 ( 7例) & 2 & 2 & 3 & 3 & 1 & 3 \\
\hline 重度 ( 7例) & 6 & 0 & 1 & 2 & 5 & 0 \\
\hline 無し(18例) & 3 & 7 & 8 & 7 & 3 & 8 \\
\hline \multicolumn{7}{|l|}{ 運動麻澣感 } \\
\hline 有り (25例) & 10 & 4 & 11 & 9 & 9 & 7 \\
\hline 無し( 7例) & 1 & 5 & 1 & 3 & 0 & 4 \\
\hline
\end{tabular}

表 2 CT の血腫分類・大きさと SEP

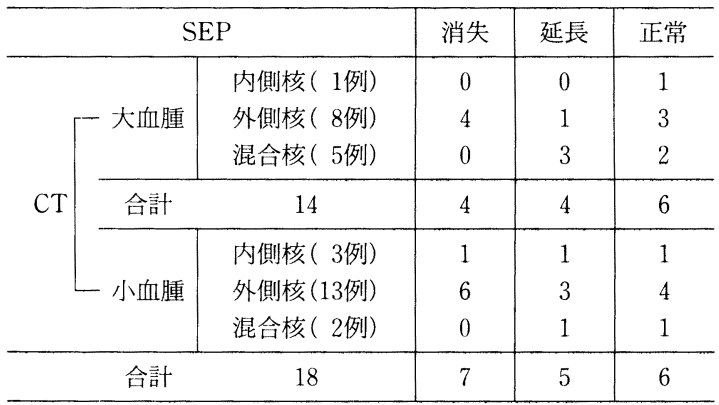

大血腫 $10 \mathrm{ml}$ 以上 小血腫 $10 \mathrm{ml}$ 末満

失し, 9 例で潜時延長が認められた。

\section{4. サーモグラム}

サーモグラムは21例（66\%）に異常がみられた. 12 例で患側低温，9例で患側高温であった．しかし，左 右差を $2^{\circ} \mathrm{C}$ 以上とした場合は, 4 例のみが異常であり, 低温 1 例, 高温 3 例であった。寒冷負荷はサーモグラ
厶上正常の 3 例中 2 例と，高温の 1 例に皮膚温回復過 程の異常がみられた. 正常の 1 例と低温の 1 例と高温 の 3 例は皮膚温回復過程は正常であった。

\section{5. 臨床症状と SEP（表 1）}

しびれ感を自覚する21例では，16例（76\%）にSEP の異常（波形消失 10 例，潜時延長 6 例）が存在した。 しかし，しびれ感がない11例では, SEP の異常は 4 例 （36\%）（消失 1 例，延長 3 例）にすぎず，しびれ感を 自覚する症例に SEP の異常が多くみられた。冷感を自 覚する 8 例中 6 例で異常 $(75 \%$ )（消失 2 例, 延長 4 例） があった。冷感がない24例中の 14 異常例 (58\%)（消失 9 例, 延長 5 例) に比べ, 冷感を自覚する症例に SEP の異常がやや高率であった. 熱感を自覚する 3 例では, 2 例 $(67 \%)$ でSEP の患側波形が消失していた．自発 痛がある 4 例は，2 例 $(50 \%)$ SEP の異常（消失 1 例, 延長 1 例）があり，自覚的感覚障害を呈するもの はしびれ, 冷感, 熱感, 自発痛の順に SEP の異常が多 く存在した。 
表在感覚低下を有する19例中12例にSEPの異常 （63\%）（消失10例, 延長 2 例）がみられたが, 表在感 党正常例でも 8 例に異常 (62\%)（消失 1 例, 延長 7 例) が存在した。垂度表在感覚低下例では 11 例中 9 例 （82\%）に異常（消失 8 例, 延長 1 例）がみられた。し かもこの重度表在感覚低下例では, SEP の波形消失が 高率であった．深部感覚低下の14例では，10例(71\%) に異常（消失 8 例, 延長 2 例）があった。深部感覚正 常例では，18例中 10 例（56\%）の異常（消失 3 例，延 長 7 例）であり，重度の深部感覚低下では 7 例中 6 例 (86\%) にSEP の消失がみられた。このように深部感 覚障害例にSEP の異常が多くみられた。しかも重症梁 部感覚低下例で, 波形消失が著しかった。

運動麻痺がある25例では，SEP 異常は14例（56\%） (消失10例, 延長 4 例) であったが, 麻痺のない 7 例で も 6 例が異常 (86\%)（消失 1 例，延長 5 例）であり, 運動麻痺と SEP の異常の間には特に関連が認められ なかった。

\section{6. 臨床症状とサーモグラム（表 1 ）}

しびれ感を自覚した21例中サーモグラムに異常がみ られたものは 14 例 $(67 \%)$ (低温 8 例, 高温 6 例)であっ た。しかし, しびれ感を自覚しない 11 症例にも, 異常 7 例 (64\%)（低温 4 例, 高温 3 例) がみられた。自発 痛を自覚する 4 例では，4 例全例（100\%）に異常（低 温 3 例, 高温 1 例）がみられた。冷感を自覚する 8 症 例では， 4 例 $(50 \%)$ に患側低温，2 例 $(25 \%)$ で高 温の異常があった。, 熱感を自覚する 3 症例では, 2 例 $(67 \%)$ に患側高温の異常がみられた。このよう に冷感や熱感を自覚する症例では, サーモグラムでも その傾向があったが, 正常例でもサーモグラム異常例 が多く有意な差はなかった。

表在感覚低下19例は，13例（68\%）に異常（低温 4 例, 高温 9 例)がみられたが, 表在感覚正常13例でも, 患側低温が 8 例（62\%）に存在した。また，重度表在 感覚低下11例では低温が 3 例（27\%）にみられたが, 高温も 6 例（55\%）あり，両者を合わせると $82 \%$ と多 かった。深部感覚低下14例は，11例 (79\%) に異常（低 温 5 例, 高温 6 例) があった。深部感覚正常18例では, 10例（56\%）に異常（低温 7 例，高温 3 例）がみられ た. また, 重度深部感覚障害の 7 例は全例に異常（低 温 2 例，高温 5 例）を認めた。

運動麻痺がある症例ではサーモグラムの異常は18例 （72\%）（低温 9 例，高温 9 例）であった。麻痺がない 症例ではサーモグラム異常は 3 例（43\%）のみ低温で
あり，麻痺を有するものにサーモグラム異常例が多 かった。

罹病期間に抢ける, サーモグラムの関係は，3 3 月 未満の症例は 9 高温例中 7 例を占め, 3 力月以上のも のは 2 例のみと 3 力月以上で著しく減少している. 反 対に低温の 12 例中 3 力月未満のものは 3 例であり, 3 カ月以上のものは 9 例と発症後の早い時期には高温例 が多く慢性期になると低温例が多かった（表 3 ）。

\section{CT と SEP (表 2)}

血腫の大きさでは, 小血腫18症例中12例（67\%）に SEP の異常（消失 7 例, 延長 5 例）を, 大血腫症例で は 8 例 $(57 \%$ ) に異常（消失 4 例, 延長 4 例）があり, 血腫の大きさと SEP の異常には関連を認めなかった。 血腫の部位では, 内側核型 4 症例中 2 例 $(50 \%)$ に SEP の異常（消失 1 例, 延長 1 例）を, 外側核型 21 症 例中14例 (67\%) に異常（消失10例, 延長 4 例）があ り，また混合型 7 症例は 4 例 (57\%)に SEP 延長のみ がみられた。外側核型で SEP 異常, 特に波形の消失を 示す症例がやや多かった.

\section{CT とサーモグラム (表 4)}

血腫の大きさでは, 小血腫18症例中 9 例 $(50 \%)$ に サーモグラムの異常（低温 5 例, 高温 4 例）を, 大血 腫14症例では12例（86\%）に異常（低温 7 例，高温 5 例）がみられた. 大血腫症例の方が小血腫症例より高

表 3 サーモグラムと罹病期間

\begin{tabular}{c|c|c}
\hline \multirow{2}{*}{ サーモグラム } & \multicolumn{2}{|c}{ 罹病期間 } \\
\cline { 2 - 3 } & $\begin{array}{c}\text { 3 カ月未満 } \\
(14 \text { 例 })\end{array}$ & $\begin{array}{c}3 \text { 力月以上 } \\
\text { (18例) }\end{array}$ \\
\hline 高温 & 7 & 2 \\
低温 & 3 & 9 \\
正常 & 4 & 7 \\
\hline
\end{tabular}

表 4 CT の血腫分類・大きさとサーモグラム

\begin{tabular}{|c|c|c|c|c|c|}
\hline \multicolumn{3}{|c|}{ サーモグラム } & 低温 & 高温 & 正常 \\
\hline \multirow{7}{*}{ CT } & & 内側核 (1例) & 1 & 0 & ) \\
\hline & －大血腫 & 外側核 ( 8例) & 2 & 5 & 1 \\
\hline & & 混合核 ( 5例) & 4 & 0 & 1 \\
\hline & 合計 & 14 & 7 & 5 & 2 \\
\hline & \multirow{3}{*}{ - 小血腫 } & 内側核 (3例) & 0 & 1 & 2 \\
\hline & & 外側核 (13例) & 4 & 3 & 6 \\
\hline & & 混合核 ( 2例) & 1 & 0 & 1 \\
\hline \multicolumn{3}{|c|}{ 合計 } & 5 & 4 & 9 \\
\hline
\end{tabular}

大血腫 $10 \mathrm{ml}$ 以上 小血腫 $10 \mathrm{ml}$ 未満 
表 5 SEP とサーモグラム

\begin{tabular}{c|c|c|c}
\hline \multirow{2}{*}{ SEP } & \multicolumn{3}{|c}{ サーモグラム } \\
\cline { 2 - 4 } & 低温(12例) & 高温(9 例) & 正常(11例) \\
\hline 消失(11例) & $3(27 \%)$ & $4(36 \%)$ & $4(36 \%)$ \\
延長( 9例) & $5(56 \%)$ & $1(11 \%)$ & $3(33 \%)$ \\
正常(12例) & $4(33 \%)$ & $4(33 \%)$ & $4(33 \%)$ \\
\hline
\end{tabular}

（）内は32症例に対する比率

率にサーモグラムの異常を呈した。

血腫の部位では，内側核型で 4 例中 2 例 $(50 \%) に$ •サーモグラムの異常（低温 1 例, 高温 1 例）がみられ, 外側核型では21例中14例に異常 $(67 \%)$ （低温 6 例，高 温 8 例)があった。また，混合型では 7 例中 5 例 (71\%) に患側低温例がみられた。サーモグラムの異常は外側 核型と混合型にてより多い傾向があった。

\section{SEP とサーモグラフィー（表 5 )}

SEP 異常20症例中13例（65\%）にサーモグラム異常 例があった。従って SEP とサーモグラムの両者の異常 は全32症例中13例 (41\%) であった. しかし SEP 正常 12症例でも 8 例（67\%）にサーモグラム異常例が存在 した.

\section{考 察}

視床出血は高血圧性脳出血全体の約 3 割を占める. Kumral ら ${ }^{14)}$ によると視床出血の100例中25例が死亡, 8 例は無症状で, 残る57例が何らかの神経学的脱落症 状が存在していた。その中でも視床症候群はまれで あったという. 今回の我々の症例の訴えはしびれ感が $66 \%$ と多く, これに冷感, 熱感などの訴えが続くが, 視床痛は少なかった. また鈴木 ${ }^{15)}$ や小田島ら ${ }^{16)}$ は, 脳 血管障害における四肢の皮虜温の変化をサーモグラ フィーで検討しているがいずれも運動麻痺の存在に重 きがおかれており，本稿の如く患者の自覚するしびれ 感, 冷感や熱感について検討した報告は見当たらない。 視床出血の CT 分類は, 金谷ら ${ }^{17}$, 神野ら ${ }^{18)}$, Kuwral $ら^{14)}$, 水上ら ${ }^{19)}$ などによりなされているが, いずれも急 性期臨床症状としての意識障害や運動麻痺について予 後との関連について検討している.また栗田ら ${ }^{201}$ は, 第 三脳室の中点, 側脳室前角外側線, 側脳室三角部外側 線を基点として 3 群に分類し， $4 \mathrm{~cm}$ 以上の劇症型は除 外して, 意識障害と運動麻痺に関して検討し,さらに 感覚障害は外側進展に相関するとも報告した。しかし, いずれも自覚的感覚障害を含め, 感覚障害の程度やそ の部位に関する検討に欠けている。
水上ら ${ }^{20}$ は, 視床出血を病理学的に, 外側核に分布す る視床膝状体動脈の破綻による外側核出血, 内側核に 分布する視床穿通動脈の破綻による内側核出血，両者 の混合による全出血と分類した。これにより臨床的に 視床諸核における神経症状の特徵を明らかに示すこと ができると報告した。我々は, CT 上血腫の主体が視床 内の内側髄板の内側に存在するか, 外側に存在するか により分類し，外側核型，内側核型，混合型に分類し 検討した. しかし, 本研究で外側核型が $66 \%$ と多い傾 向にあったのは, 内側核型症例は症状を残さずに改善 してしまうため本研究の対象から除外されているため とも考えられた。

視床出血における SEPについては, すでに多くの報 告があり, N18(N20)-P24成分の低振幅化, 消失, 潜 時延長などが起こることが知られている ${ }^{21)}$. また工藤 ら ${ }^{22)}$ は, 発症時に消失していた N19 (N20)-P23頂点 は, 触覚, 痛覚, 振動覚および固有感覚の臨床的改善 に伴って回復することを報告している。 また, Chiang ら ${ }^{23)}$ は, 視床出血患者の $93 \%$ にEP の異常があり, postero-lateral 群では，すべての SEP 成分が障害さ れていたと報告している。今回の結果では, SEPの異 常は63\%と低率であったが, 症例が慢性期例で, 症状 の程度も軽度な例が多く含まれていることも関係して いると考元られる.中西ら ${ }^{12)}$ は, N20の消失は入院時の 麻痺や感覚障害に関係なく実用手にならなかったと報 告していた。我々も, 表在感覚・深部感覚の障害と SEP の異常は,特に感覚障害の程度が強いものに SEP 波形 消失が多くみられ，その関連が認められた。しかし， 感覚正常例にも SEP の異常があり, 感覚障害の評価や SEP の判定に関してさらに検討が必要である.SEP は 体性感覚路障害を評価する方法であり, 運動麻痺と SEP の関連は見られなかった。

自覚的感覚障害と SEP に関する検討は過去に報告 がなく, 今回我々の検討は初めてである，患者の訴え であるしびれ感や冷感，熱感，自発痛を客観的に評価 する場合にそれらの訴えがある症例に SEP の異常を 高率に認めたことは，自覚的感覚障害であっても表在 覚や深部覚と同様に感覚障害として客観的に評価でき ることが示唆された。

サーモグラフィーは皮膚表面温度を表す機能検査で あり ${ }^{24)}$ ，その利用は多方面に及んでいる ${ }^{16) 25226)}$. 最近, 中枢性疾患にも応用されているが16)26) 28), 脳卒中での 報告はまだ少ない( ${ }^{16) 28}$. Wanklyn ら ${ }^{28)}$ は，脳卒中後の 運動麻痺患者に関して, 麻痺側の cold arm を自覚す 
る症例は，21例中11例と半数以上を占め, サーモグラ ムで，患側が平均 $0.65^{\circ} \mathrm{C}$ 低下していると報告した。ま た，cold arm の症例の未梢の血流を測定し，患側では 健側に比較して $35 \%$ 減少しているとも報告した。木原 $ら^{299}$ も同様に四肢末梢の血流障害に基づいて，足背の 皮膚温が低下すると報告している，反対に表面皮膚温 の上昇に扔いては，手山 ${ }^{2}$ は自律神経障害による血管 運動麻痺によるもので，その核は前核に存在するらし いと言っている。

本稿のサーモグラムの結果では発症後早期には高温 例が多く，慢性期には低温例が多かった。木原ら ${ }^{29}$ は, これらの原因が交感神経緊張状態が発症後 1 力月以上 の経過をもって徐々に発現して来ると推定している. また, 本研究では, 外側核型の外側腹側核や後外側腹 側核などの出血例でサーモグラムの異常を多く示した ことより，これらの核か，またはその周囲組織も自律 神経系に何らか関与しており，障害されることにより 皮虐表面温度が低温，高温になったりすることも考え られる。

サーモグラフィーの負荷には, 冷水, 温熱, 血流遮 断などいろいろある ${ }^{24)}$ が, 本研究では, 寒冷負荷の回復 過程に異常がみられた。特に，サーモグラムにより皮 膚表面温度では左右差なく，正常と思われた症例の中 に，寒冷負荷により異常がみられたものが多くあり， 負荷をかけることにより厳密なサーモグラムの評価が できるものと考えられた. SEP での潜時延長はサーモ グラム上での上肢刺激部位の温度低下が原因するとも 考えられるが, 今回の研究では,これを確認できなかっ た. 本研究では, CT 上外側核型に両者の異常が著しく 多く，しかも，サーモグラムと SEP の間にも相関関係 を見いだせた。これらは，寒冷など負荷したサーモグ ラフィーを行うことなどによりさらに何らかの関係が 見いだせるのではないかと思われ，今後の研究課題で もある。

\section{文献}

1) Dejerine J: Semiologie des affections du systeme nerveux. Masson et Cie, Paris, 1914

2) 平山惠造：視床症候群。神経症候学, 東京, 文光堂, 1976, pp966-980

3) Hirai $T$, Jones EG: A new parcellation of the basis of histochemical staining. Brain Research Reviews $14: 1-34,1989$

4）大江千廣：視床の機能的マッピング. 脳外科 24 ：
$501-506,1996$

5）静 雅彦, 長田 乾, 柚木和太ら：視床出血-CT 上の血腫の広がりと臨床症状の解析一, 脳卒中 $2: 255-261,1980$

6）中尾 哲, 南川 順, 大山憲治ら：高血圧性脳出血 の現状一入院後転㷌不良症例の検討から一. ICH' 95抄録集 (名古屋)：87，1995

7）半田 肇，米川泰弘：脳神経外科の手術対象とな りうる脳卒中出血性病変. 喜多村孝一, 亀山正邦 (編)：脳卒中一基礎と臨床一, 東京, 朝倉書店, 1979, pp199-211

8）鈴木明文，伊藤善太郎：視床部出血における体性 感覚誘発電位. 臨床脳波 $20: 394-403,1978$

9）竹内茂和, 新井弘之, 山崎一徳ら：脳内血腫例にお ける非出血側体性感覚誘発電位の検討. 脳外科 $17: 37-40,1989$

10）橋本隆男, 宮坂元磨, 藤田 勉ら：延髄内側症候群 (Dejerine 症候群) の磁気共鳴画像と短潜時体性感 覚誘発電位. 臨床神経 30: 587-593, 1990

11) Gott PS, Karnaze DS, Fisher M, et al : Assessment of median nerve somatosensory evoked potentials in cerebral ischemia. Stroke $21: 1167$ $-1171,1990$

12）中西亮二, 衛籐誠二, 寺本靖之ら：視床出血におけ る正中神経刺激短潜時体性感覚誘発電位. 臨床脳 波 36: 35-38, 1994

13）衛䈋誠二, 古閑公治, 上床太心ら：被殼出血に抢け る正中神経刺激短潜時体性感覚誘発電位と上肢機 能. リ八医学 $33: 310-315,1996$

14) Kumural E, Kocaer T, Ertubey NO, et al : Thalamic Hemorrhage. A Prospective Study of 100 Patients. Stroke 26: 964-970, 1995

15）鈴木秀徳：脳血管障害における四肢皮膚温変化 発症後経過期間, 合併症, 神経微候 頭部 CT 所見 との関連について. Biomedical Thermology 9: $251-263,1989$

16）小田嶋奈津, 沖山亮一, 松本高志ら：脳血管障害後 の片麻痺患者における皮膚血管拡張反応一サーモ グラフィーによる検討一. Biomedical Thermology 8:140-142, 1988

17）金谷春之, 湯川英機, 神野哲夫ら：高血圧性脳出血 に打ける新しいNeurological Grading 抢よび CTによる血腫分類とその予後について。高血圧 性出血の外科 III：265-270, 1978

18）神野哲夫, 片田和広, 香川泰生ら：視床出血その CT 所見と治療。脳外科 $5: 541-548,1977$ 
19）水上公宏, 金 弘, 荒木五郎ら：視床出血一その分 類と臨床像一。脳神経 27:195-206,1975

20）栗田浩樹, 古屋一英, 瀬川 弘ら：視床出血の局在 と神経症状. 脳外科 $22: 537-543,1994$

21) Noel P, Desmedt E: Somatosensory cerebral potentials after vascular lesions of the brainstem and diencepharon. Brain 98: 113-128, 1975

22）工藤 寛, 山鳥 重: 視床出血における SEP の経 時的変化. 脳卒中 $6: 195-203,1984$

23) Chiang TR, Chiu HC: Shoort-and long latency median nerve somatosensory evoked potentials in stroke patients. J Formosan Med Assoc 88 : 778-784, 1989

24）鹿野昌彦：負荷サーモグラフィーについて. Biomedical Thermology 14:162-166, 1994
25）人位 晃, 松岡 瑛：機能画像(サーモグラフィー を中心に)を用いた末梢循環動態の病態生理学的 解析. 臨床病理 38:1119-1125, 1990

26）小柳泉, 岩崎喜信, 井須豊彦ら：脊䯣空洞症に対 するサーモグラフィーの経験. 脳外科 16:1149 -1154, 1988

27）橋本卓雄, 中原成浩, 関野宏明ら：脳神経外科領域 における赤外線サーモグラフィーの応用一開頭時 の脳皮質の温度変化一. Biochemical Thermology 4:76-78, 1984

28) Wanklyn P, Ilsley DW, Greensteind D, et al: The cold hemiplegic arm. Stroke 25: 17651770, 1994

29）木原幹洋, 佐藤 功, 高橋 昭ら：脳血管障害に伴 う片麻痺患者の足背皮膚温変化. 自律神経 21 : $399-404,1984$

\section{Abstract \\ Evaluation of neurologic sequelae of thalamic hemorrhage based on somatosensory evoked potentials and thermography}

Keihei Chou, M.D., Mitsuyasu Nagasaka, M.D. and Tsuneo Shimizu, M.D.

Department of Neurosurgrey, Kantou Neurosurgical Hospital

The usefulness of somatosensory avoked potential (SEP) recording and thermography for evaluating the symptoms and signs caused by thalamic hemorrhage was investigated in 32 patients. Most patients complained of sensory numbness (21) and coldness (8) of the impaired extremities, and few complained of warmth (3) or pain (4). Clinical signs of superficial sensory disturbance were observed in 19 patients, deep sensory disturbance in 14 , and hemiparesis in 25 . Computed tomography demonstrated that the thalamic hemorrhages were of the type located in the lateral nucleus in 21 patients of that in the medial nucleus in 4 and of the mixed type in 7 . SEP recording revealed that 16 of 21 patients with numbness, 6 of 8 with coldness, 9 of 11 with severe superficial sensory disturbance, and 6 of 7 with severe deep sensory disturbance had either absence or prolonged latency of the N20 wave. Thermography demonstrated an abnormally high or low skin temperature on the impaired extremities as compared with the uninvolved side in 14 of 21 patients with numbness, 9 of 11 with severe superficial sensory disturbance, 7 of 7 with severe deep sensory disturbance. 18 of 25 with hemiparesis, and 12 of 14 with large hematoma. Thirteen of 20 patients with SEP abnormality had abnormal skin temperatures on their thermograms. Severe superficial and deep sensory disturbance was correlated with an abnormal SEP and thermography findings in patients with lateral nucleus hemorrhage. SEP recording is considered useful for the evaluation of severe clinical sensory disturbance, and thermography for investigating severe subjective and clinical sensory disturbances.

(Jpn J Stroke 19: 19-25, 1997) 